\title{
ABO phenotypes and malaria related outcomes in mothers and babies in The Gambia: a role for histo-blood groups in placental malaria?
}

\author{
María-Paz Loscertales ${ }^{1}$ and Bernard J Brabin*1,2,3
}

Address: ${ }^{1}$ Child and Reproductive Health Group, Liverpool School of Tropical Medicine, Liverpool, UK, ${ }^{2}$ Emma Kinderziekenhuis, Academia Medical Centre, University of Ámsterdam, The Netherlands and ${ }^{3}$ Department of Community Child Health, Royal Liverpool Children's Hospital, Alder Hey NHS Trust, Liverpool, UK

Email: María-Paz Loscertales - incomati@hotmail.com; Bernard J Brabin* - b.j.brabin@liv.ac.uk

* Corresponding author

Published: 17 August 2006

Malaria Journal 2006, 5:72 doi:10.1186/1475-2875-5-72
Received: 16 June 2006

Accepted: 17 August 2006

This article is available from: http://www.malariajournal.com/content/5///72

(c) 2006 Loscertales and Brabin; licensee BioMed Central Ltd.

This is an Open Access article distributed under the terms of the Creative Commons Attribution License (http://creativecommons.org/licenses/by/2.0), which permits unrestricted use, distribution, and reproduction in any medium, provided the original work is properly cited.

\begin{abstract}
Background: Host susceptibility to P.falciparum is critical for understanding malaria in pregnancy, its consequences for the mother and baby, and for improving malaria control in pregnant women. Yet host genetic factors which could influence placental malaria risk are little studied and there are no reports of the role of blood group polymorphisms on pregnancy outcomes in malaria endemic areas.

This study analyses the association between $A B O$ blood group phenotypes in relation to placental malaria pathology.

Methods: A total of 198 mother/child pairs delivering in Banjul and the Kombo-St Mary District (The Gambia) were analysed. ABO blood group was measured by agglutination. Placental malaria parasites wee enumerated and the presence of malaria pigment noted. Birth anthropometry was recorded and placental weight. Maternal and infant haemoglobin was measured.
\end{abstract}

Results: 89 (45\%) subjects were primiparae and IIO (55\%)multiparae. The ABO phenotype distribution was 38(A), 52(B), 6(AB) and 102(O). Placental histo-pathology showed active placental malaria in $74(37 \%)$, past infection in $42(21 \%)$ and no infection in 82 cases $(41 \%)$. In primiparae blood group $\mathrm{O}$ was associated with a higher risk of active infection $(\mathrm{OR}=2.99 ; 95 \% \mathrm{Cl}=1.24$ $7.25)$, and a lower risk of past infection (OR $=0.31,0.10-1.0 \mathrm{I}, \mathrm{p}<0.05)$. In multiparae the $O$ phenotype was associated with reduced prevalence of active or past placental infection $(O R=0.45$; $95 \% \mathrm{Cl} 0.21-0.98)$. The mean feto-placental weight ratio was significantly higher in multiparae with group $O$ women compared to non-O phenotypes ( 5.74 vs $5.36 ; \mathrm{p}=0.04$ ). Among primiparae with active placental infection, mean birth weight was higher in children of mothers with the $O$ phenotype $(p=0.04)$.

Conclusion: These results indicate that blood group $O$ was significantly associated with increased placental malaria infection in primiparae and reduced risk of infection in multiparae. This parity related susceptibility was not present with other $A B O$ phenotypes. Cell surface glycans, such as $A B O$ and related antigens have special relevance in reproductive biology and could modulate specific cell interactions as those associated with the pathogenesis of placental malaria. 


\section{Background}

In malaria endemic areas, the increased risk of $P$. falciparum infection during pregnancy, which is associated with placental parasitaemia, imposes a heavy burden on the health of mothers and newborns [1,2], contributing to maternal anaemia, low birth weight, and infant mortality especially among primiparae [3,4]. At present, available preventive and therapeutic tools can only achieve a partial reduction in the health hazards caused by placental malaria $[5,6]$. In this context, a better knowledge of host susceptibility to placental P.falciparum infection is central for improving understanding of malaria in pregnancy, as a basis for improved control.

There is increasing evidence that both the risk of acquiring $P$. falciparum infection, and the risk of developing severe complications are determined by host genetic factors [7]. The protective role of several erythrocytic variants, some of them related to blood groups, is one of the best examples of this genetic modulation [8]. These include haemoglobins S, C and E, $\alpha$ and $\beta$ thalassaemias, Glucose- 6 phosphate dehydrogenase deficiency, Southern Asian Ovalocytosis, and Glycophorins A, B and C variants, all of which influence malaria pathogenesis [9].

ABO blood groups are carbohydrate histo-blood antigens that are also expressed in many tissues and which have important roles in modulating protein activities both in infection and in some types of cancer [10]. These antigens are formed by terminal glycosylation of glycoproteins and glycolypid chains present on cell surfaces. Glycosylation modulates all kinds of cell-to-cell interactions and this may be relevant in malaria pathophysiology, where adhesion has been increasingly implicated in disease severity. Studies examining the effects of the ABO blood group phenotype on malaria risk in non-pregnant subjects, have shown inconsistent results [11-13]. Blood group A has been reported as a risk factor for severe malaria [14], and as a co-receptor for P.falciparum resetting [15], whereas blood group $\mathrm{O}$ may offer some protection against severity of disease [16].

No studies have been identified in the literature assessing associations of blood group types with placental malaria, despite the fact that placental parasites are unable to rosette [17], in contrast to isolates from non-pregnant subjects. Cell surface glycans have an essential role in reproductive biology, and the adhesion and implantation of the blastocyst is partly mediated by carbohydrates with blood group specificity [18]. Each mammalian species has its own glycotype at the feto-maternal interface, and this variation depends on both evolution and the environment [19]. ABO histo-blood groups and related antigens are expressed in the endometrium and are modulated by the hormonal environment [20], but are not expressed in the placenta and fetal endothelium where only other related blood groups can be detected in the interstitial trophoblast directly apposed to the maternal decidua [21]. In contrast, examination of the glycan expression at the fetomaternal interface using lectins, some with $\mathrm{ABO}$ determinant specificity have shown binding with placental structures $[22,23]$.

In this analysis we present the first report to describe the association between $\mathrm{ABO}$ phenotypes, placental malaria and pregnancy outcomes.

\section{Materials and methods Study sample}

Data from a group of 198 mother/child pairs were analysed from a cross-sectional study of placental malaria undertaken in the Gambia. The original descriptive study assessed serum Ig levels in mothers and newborns in relation to placental parasitaemia. The primary outcomes and a detailed description of the methodology are outlined in the original publication [24].

Mothers and their newborn babies were included in the study from September 1967 to May 1968 in Banjul and the Kombo-St Mary District (The Gambia). In this area malaria is endemic with peak transmission during and shortly after the rainy season which lasts from July to October [25]. Mothers and babies were examined soon after delivery at the Royal Victoria Hospital, Banjul, or in one of the maternal and child welfare centres in the Kombo-St Mary District. Basic demographic information was recorded. The weight $(\mathrm{g})$ and length $(\mathrm{cm})$ of the baby were measured by a physician within a few hours of birth. Placentas were transported twice daily to the Medical Research Council Laboratories where they were weighed and examined for placental pathology. Placental blood and maternal and neonatal peripheral venous blood were collected, and blood films were prepared and stained by standard methods. Parasitaemia was counted in the peripheral blood against the number of white cells, and in the placental blood by assuming that 1 parasite per 100 oil-immersion fields represented a density of 10 parasites/ $\mathrm{mm}^{3}$ blood. Maternal and infant haemoglobin was measured.

Data were entered on punch cards and for all births the following data was available: maternal age, parity, haemoglobin and peripherical parasitaemia; the babies gender, weight, length and haemoglobin. The ABO and Rhesus blood group phenotype of mother and baby were recorded and the placental weight $(\mathrm{g})$, parasite count and presence of malaria pigment. All data was entered into a SPSS data file. 


\section{Clinical definitions}

Placental malaria definition was based on the pathological classification of Bulmer et al [26], which comprises the following groups: non-infected; acute infection (presence of parasites without pigment); chronic infection (presence of parasites and pigment); past infection (parasites not present; pigment present). Acute and chronic placental malaria were also grouped as 'active' infection.

\section{Statistical analysis}

Dichotomous variables were assessed with chi-square or Fisher exact tests, with p values less than 0.05 considered statistically significant. Odds ratios and 95\% confidence intervals were estimated. Differences between means were assessed by ANOVA where data was normally distributed, or the Mann-Whitney/Wilcoxon Test. Multiple linear regression was used to analyse factors associated with anthropometric outcomes. Factors included were those significant at $\mathrm{p}=0.1$ in the univariate analysis. For anthropometric variables the factors included where: maternal blood group ( $\mathrm{O}$ versus non $\mathrm{O}$ ), parity, placental infection, maternal haemoglobin, maternal peripheral parasitaemia and maternal height.

\section{Results}

Eighty-eight of the 198 women were primiparae (45\%) who had a mean age of 17.8 years $(S D \pm 1.8)$. The mean age of multiparae was 29.7 years $( \pm 6.1)$. Placental malaria was present in 116 cases (59\%), with active placental malaria infection in $74(37.4 \%)$, of which $26(13.1 \%)$ were acute and 48 (24.2\%) chronic infections. Past infection was detected in 42 women $(21.2 \%)$. In the remaining 82 cases $(41 \%)$ there was no evidence for current or previous placental malaria. Among primiparae, 56 (63\%) had evidence of placental infection of which 41 (47\%) were active, 12 (14\%) acute and 29 (33\%) chronic infections. Among multiparae 60 (55\%) had evidence of placental infection with 33 (30\%) active, 14 (13\%) acute and 19 $(17 \%)$ chronic (Table 1). Primiparae were at increased risk for active placental malaria (OR 1.99, 95\% CI 1.11 3.57 ), and more specifically the chronic infection (OR 2.32, 95\% CI 1.19-4.5).

The male/female ratio was significantly increased in active placental malaria OR $=1.87$ (95\%CI 1.04-3.39), $\mathrm{p}=0.04$ and decreased in past infection OR $=0.45$ (95\%CI $0.22-$ $0.90), \mathrm{p}=0.02$.

There was no significant association between $\mathrm{O}$ or non-O blood groups and placental infection when parity was not considered, except for past placental malaria which was less prevalent in women with blood group O (OR 0.39, 95\% CI $0.18-0.84, \mathrm{p}<0.01)$. In primiparae blood group $\mathrm{O}$ was associated with more active placental malaria (OR $2.99,95 \%$ CI 1.24-7.25, p < 0.05) and less past placental malaria $(\mathrm{OR}=0.31,0.10-1.01, \mathrm{p}<0.05)$ than in non-O women. In multiparae, blood group $\mathrm{O}$ was significantly associated with non-infected placentae (OR 2.22, 95\% CI $1.03-4.78, \mathrm{p}<0.05)$ compared to non-O women (Table 1 ). The effect of parity on the risk of placental infection was significant for the $\mathrm{O}$ blood group sub-population with lower risk of active infection in multigravidae (OR $0.27,95 \%$ CI $0.12-0.62, \mathrm{p}<0.01$ ) compared with primiparae of the same blood group. For non-O blood groups, there were no significant parity differences in risk of active (OR 1.06, 95\%CI 0.44-2.59, p = 0.9) or past placental infection (OR 0.79, 95\%CI 0.32-1.98, p = 0.6). The effect of parity on the risk of active placental infection was significantly different for the two sub-populations $\mathrm{O}$ and non-O, (Chi-square 4.98, $\mathrm{p}=0.03$ ).

Table 2 summarises birth outcomes by blood group phenotype. In primiparae, with active placental infection, mean birth weight was significantly higher in babies born to blood group $\mathrm{O}$ mothers (2893 g versus $2639 \mathrm{~g}$, $\mathrm{p}=$ $0.04)$.

Maternal haemoglobin ( $\mathrm{Hb})$ concentration was higher in O type mothers with active placental malaria $(11.65 \mathrm{~g} / \mathrm{dl}$, versus $10.53 \mathrm{~g} / \mathrm{dl}$ ) although this difference was not statistically significant $(\mathrm{p}=0.48)$. There were no significant differences in mean infant haemoglobin, infant length, placental weight, ponderal index or placental parasitaemia prevalence by blood group category (table 2 ).

Mean feto-placental weight ratio was increased in blood group $\mathrm{O}$ compared to non-O $(\mathrm{p}=0.06)$ and was significant in multiparae (5.74 versus 5.36; $\mathrm{p}=0.04$ ), (Figure 1 ). Blood group phenotype ( $\mathrm{O}$ versus non-O) was an independent predictor of the higher feto-placental weight ratio, (linear regression coefficient $=0.26, \mathrm{p}=0.04$ ). The other malaria parameters, did not show any significant associations with blood groups on multivariate analysis.

The Rhesus blood group type showed no significant associations in relation to placental malaria categories or birth outcomes.

\section{Discussion}

Blood group $\mathrm{O}$ was associated with an increased prevalence of active placental infection in primiparae and with a reduced risk of placental malaria in multiparae. Placental parasitaemia occurs at least twice as frequently in primiparae but only among blood group $\mathrm{O}$ women. This effect of parity, that is one of the cardinal features of placental malaria, was not observed in non-O phenotypes for any of the placental malaria histological types.

In multiparae and specifically in mothers with past or non-infected placentae blood group $\mathrm{O}$ was also associated 
Table I: ABO phenotype by placental malaria category and parity group

\begin{tabular}{|c|c|c|c|c|c|c|c|}
\hline \multirow[t]{2}{*}{ Parity } & \multicolumn{2}{|c|}{ Placental malaria } & \multicolumn{4}{|c|}{ Phenotype N (\%) } & \multirow[t]{2}{*}{ OR $95 \% \mathrm{Cl} O /$ non O } \\
\hline & Type & No & A & B & $A B$ & O & \\
\hline \multirow[t]{4}{*}{ Primiparae } & Active & 41 & $6(37)$ & $6(30)$ & $0(0)$ & $29(58)$ & $2.99,1.24-7.25$ \\
\hline & Past & 15 & $4(25)$ & $4(20)$ & $2(100)$ & $5(10)$ & $0.3,0.1-1.0$ \\
\hline & None & 33 & $6(37)$ & $10(50)$ & $0(0)$ & $16(32)$ & $0.65,0.27-1.55$ \\
\hline & Total & 88 & 16 & 20 & 2 & 50 & \\
\hline \multirow[t]{4}{*}{ Multiparae } & Active & 33 & $6(27)$ & II (29) & $2(50)$ & $14(27)$ & $0.75,0.33-1.7$ \\
\hline & Past & 27 & $8(36)$ & $10(31)$ & $0(0)$ & $9(17)$ & $0.47,0.19-1.15$ \\
\hline & None & 50 & $8(36)$ & II (34) & $2(50)$ & $29(56)$ & $2.22,1.03-4.78$ \\
\hline & Total & 110 & 22 & 32 & 4 & 52 & \\
\hline
\end{tabular}

Brackets: percentage

with higher mean feto-placental weight ratios compared to non-O individuals. These differences associated with multiparity can be interpreted to represent a parity-specific association of the blood group $\mathrm{O}$ phenotype with the protective malarial immunity which occurs in multigravidae [3]. Mean birth weight was also significantly increased in babies of primiparae with the O phenotype, suggesting that despite the greater susceptibility of primigravidae to placental malaria, the $\mathrm{O}$ phenotype may be partially protective leading to improved birth anthropometry.
In non-pregnant individuals blood group $\mathrm{O}$ has been associated with reduced risk of severe clinical malaria compared to patients with groups A or B $[14,16]$, but this occurred without clear evidence for reduced prevalence of parasitaemia associated with blood group $\mathrm{O}[12,13]$. This would suggest that the ABO phenotypes may be associated more with modification of disease severity than with infection risk. None of these women had HIV infection as the study was conducted in the early 1970s before this human immunodeficiency virus was described or trans-

Table 2: Mean birth outcomes by parity and maternal blood group phenotype

\begin{tabular}{|c|c|c|c|c|c|c|c|c|c|c|c|}
\hline \multirow[b]{2}{*}{ Parity } & \multirow[b]{2}{*}{$\begin{array}{l}\text { Placental } \\
\text { Malaria } \\
\text { type }\end{array}$} & \multirow[b]{2}{*}{$\begin{array}{l}\text { Blood } \\
\text { group }\end{array}$} & \multirow[b]{2}{*}{$\mathbf{n}$} & \multicolumn{8}{|c|}{ Malaria Parameters : MEAN (SD) } \\
\hline & & & & $\begin{array}{c}\text { Maternal } \\
\text { Hb g/dl }\end{array}$ & $\begin{array}{l}\text { Infant } \\
\mathrm{Hb} \text { g/dl }\end{array}$ & $\begin{array}{c}\text { Birth } \\
\text { weight g }\end{array}$ & $\begin{array}{l}\text { Length } \\
\text { cm }\end{array}$ & $\begin{array}{l}\text { Placental } \\
\text { weight } \mathrm{g}\end{array}$ & $\begin{array}{l}\text { Pondera } \\
\text { I index } \\
(\ddagger)\end{array}$ & $\begin{array}{c}\text { Feto- } \\
\text { placental } \\
\text { weight } \\
\text { ratio }\end{array}$ & $\begin{array}{c}\text { Parasite } \\
\text { count } \\
(\log 10)\end{array}$ \\
\hline \multirow[t]{4}{*}{$\begin{array}{l}\text { Primipa } \\
\text { rae }\end{array}$} & Active $(\dagger)$ & O group & 29 & $11.65(1.6)$ & $18.5(3.1)$ & $\begin{array}{c}2893 \\
(362)^{*}\end{array}$ & $49.0(1.8)$ & $559(123)$ & $\begin{array}{l}2.51 \\
(0.24)\end{array}$ & $5.26(0.9)$ & $\begin{array}{c}2.74 \\
(1.36)\end{array}$ \\
\hline & & non-O & 12 & $10.53(3.1)$ & $19.4(3.0)$ & $\begin{array}{c}2639 \\
(323)^{*}\end{array}$ & $47.9(1.9)$ & $513(115)$ & $\begin{array}{c}2.45 \\
(0.15)\end{array}$ & $5.3(0.9)$ & $\begin{array}{c}3.18 \\
(1.48)\end{array}$ \\
\hline & $\begin{array}{l}\text { Past or no } \\
\text { infection }\end{array}$ & O group & 21 & $12.0(1.3)$ & $18.2(2.2)$ & $\begin{array}{l}2941 \\
(455)\end{array}$ & $48.6(1.6)$ & $544(135)$ & $\begin{array}{c}2.59 \\
(0.22)\end{array}$ & $5.62(1.22)$ & \\
\hline & & non-O & 26 & $11.8(2.3)$ & $18.2(2.0)$ & $\begin{array}{l}2894 \\
(430)\end{array}$ & $48.9(1.8)$ & $559(100)$ & $2.5(0.21)$ & $5.28(0.9)$ & \\
\hline \multirow[t]{4}{*}{$\begin{array}{l}\text { Multipar } \\
\text { ae }\end{array}$} & Active & O group & 14 & $11.9(1.4)$ & $18.5(2.0)$ & $\begin{array}{l}3151 \\
(705)\end{array}$ & $49.7(2.4)$ & $578(124)$ & $\begin{array}{c}2.55 \\
(0.26)\end{array}$ & $5.53(1.15)$ & $\begin{array}{c}2.28 \\
(1.19)\end{array}$ \\
\hline & & non-O & 19 & $12.3(1.5)$ & $18.7(2.5)$ & $\begin{array}{l}3366 \\
(312)\end{array}$ & $50.0(1.8)$ & $652(169)$ & $\begin{array}{c}2.68 \\
(0.20)\end{array}$ & $5.39(1.1)$ & $\begin{array}{c}2.53 \\
(1.18)\end{array}$ \\
\hline & $\begin{array}{l}\text { Past or no } \\
\text { infection }\end{array}$ & O group & 38 & $12.2(1.5)$ & $18.6(2.1)$ & $\begin{array}{l}3315 \\
(537)\end{array}$ & $49.8(2.3)$ & $580(121)$ & $\begin{array}{c}2.67 \\
(0.24)\end{array}$ & $\begin{array}{c}5.82 \\
(0.85) \S\end{array}$ & \\
\hline & & non-O & 39 & II.8 (I.5) & I8.7 (2.3) & $\begin{array}{l}3093 \\
(521)\end{array}$ & $49.1(2.0)$ & $588(115)$ & $\begin{array}{c}2.67 \\
(0.23)\end{array}$ & $\begin{array}{c}5.34 \\
(0.89) \S\end{array}$ & \\
\hline
\end{tabular}

†Active: acute and chronic infection

$\ddagger$ Ponderal Index $=$ weight/length3

$* \mathrm{p}$ value $=0.04$

$\S \mathrm{p}$ value $=0.02$ 


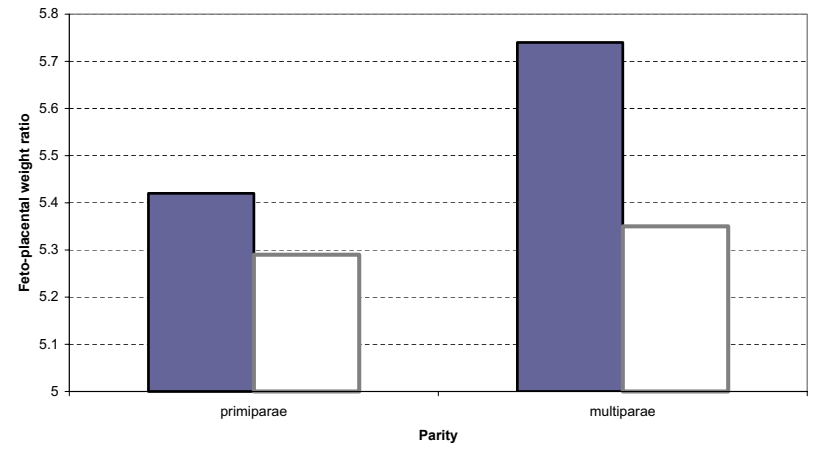

\section{Figure I}

Mean feto-placental weight ratio in primiparae and multiparae according to blood group. Shaded blood group $O$, white non-O groups

mitted. This indicates that these results are not confounded by an immunosuppressive effect of HIV virus infection.

This is the first time an association of birth outcomes with placental malaria and maternal ABO phenotype has been reported. This raises the question of the possible mechanisms underlying the association. A central mechanism in the pathogenesis of placental malaria relates to the cytoadherence of infected red cells to the syncytiotrophoblast which is in contact with maternal blood. The parity related susceptibility to placental malaria is partly dependent on the selection of P.falciparum isolates which bind to trophoblast via chondroitin sulphate A (CSA) [27] and hyaluronic acid [28]. Infected red cells can also bind to the proteoglycan thrombomodulin, present on endothelial cells and placental syncytiotrophoblast, via CSA side chains [29]. Soluble adhesion molecules and endothelial markers (including won Willebrand factor and E-selectin) are associated with $\mathrm{ABO}$ phenotypes, especially thrombomodulin which is lower in group $\mathrm{O}$ and $\mathrm{A}$ than B plasma $(\mathrm{P}<0.001)[30]$.

Duffy binding-like domains (DBL) of the P. falciparum erythrocyte membrane protein 1 (PfEMP1) mediate binding to several independent host receptors [31] and in placental isolates it is the DBL- $\gamma 3$ domain which binds to chondroitin sulfate A (CSA) in syncytiotrophoblast $[32,33]$. However, there is no published evidence of an association between DBL- $\gamma 3$ and the ABO phenotype, although it has been shown that the DBL1 $\alpha$ domain has an affinity for the blood group A antigen [34].

The interaction between the ABO histo-blood group and placental malaria could relate to generic mechanisms affecting P.falciparum infection. For example the differen- tial affinity of each phenotype for A.gambiae [35], or antigen sharing between $\mathrm{ABO}$ phenotypes and P.falciparum leading to changes in immune response [36], or an association with Glycophorin A (GPA) which is an important determinant for P.falciparum entry into the red cell through GPA sialic acid, as $\mathrm{ABH}$ antigens have been described in the O-glycans of glycophorin A [37]. In addition $\mathrm{ABO}$ phenotypes differ in sialic acid content and composition, with group $\mathrm{O}$ showing the highest membrane content, but a lower percentage of sialoglycoproteins [38].

It is well known that host genetic factors modulate the risk and severity of infection. In most cases these are genetic variants with subtle effects on the regulation or function of specific mediators which are often difficult to demonstrate in epidemiological studies [39]. As there is increasing evidence that cell adhesion plays a decisive role in placental malaria pathophysiology, it is clear that cell surface glycans, such as the ABO and related antigens which have special relevance in reproductive biology, could modulate some of those specific cell interactions. Their association with placental malaria risk, birth outcomes and parity related susceptibility, provides a new insight into these interactions and into the role of glycosylation and host-specific genetic factors in placental malaria.

\section{Acknowledgements}

The authors express their thanks for the permission of Professor Sir lan McGegor for providing the punch cards from which this data was extracted, and for agreeing to this analysis.

\section{References}

I. Brabin BJ, Hakimi M, Pelletier D: An analysis of anemia and pregnancy related maternal mortality. Journal of Nutrition $200 \mathrm{I}$, | 34 |:604-| 5.

2. Guyatt HL, Snow RW: Impact of malaria during pregnancy on low birth weight in sub-Saharan Africa. Clin Microbiol Rev 2004, I 7(4):760-9.

3. Brabin BJ: An analysis of malaria in pregnancy in Africa. Bull World Health Organ 1983, 6 I(6): I005-I6.

4. McGregor IA, Wilson ME, Billewicz WZ: Malaria infection of the placenta in The Gambia, West Africa; its incidence and relationship to stillbirth, birthweight and placental weight. Trans $R$ Soc Trop Med Hyg 1983, 77(2):232-44.

5. Garner P, Gulmezoglu AM: Prevention versus treatment for malaria in pregnant women. Cochrane Database Syst Rev 2000:CD000169.

6. Garner P, Gulmezoglu AM: Drugs for preventing malariarelated illness in pregnant women and death in the newborn. Cochrane Database Syst Rev 2003:CD000169.

7. Fortin A, Stevenson MM, Gros P: Susceptibility to malaria as a complex trait: big pressure from a tiny creature. Hum $\mathrm{Mol}$ Genet 2002, I I(20):2469-78.

8. Min-Oo G, Gros P: Erythrocyte variants and the nature of their malaria protective effect. Cell Microbiol 2005, 7(6):753-63.

9. Pasvol G: How many pathways for invasion of the red blood cell by the malaria parasite? Trends Parasitol 2003, I 9( I 0):430-2.

10. Greenwell P: Blood group antigens: molecules seeking a function? Glycoconjugate Journal 1997, I4(2): 159-173.

II. Migot-Nabias F, Mombo LE, Luty AJ, Dubois B, Nabias R, Bisseye C, Millet $\mathrm{P}, \mathrm{Lu} \mathrm{CY}$, Deloron $\mathrm{P}$ : Human genetic factors related to susceptibility to mild malaria in Gabon. Genes Immun 2000, I (7):435-4I. 
12. Pant CS, Srivastava HC: Distribution of three genetic markers and malaria in other backward castes of Kheda district, Gujarat. Indian J Malariol I997, 34(I):42-6.

13. Pant CS, Gupta DK, Bhatt RM, Gautam AS, Sharma RC: An epidemiological study of G-6-PD deficiency, sickle cell haemoglobin, and $A B O$ blood groups in relation to malaria incidence in Muslim and Christian communities of Kheda, Gujarat, (India). J Commun Dis 1992, 24:199-205.

14. Fischer PR, Boone P: Short report: severe malaria associated with blood group. American Journal of Tropical Medicine and Hygiene 1998, 58: 122-3.

15. Barragan A, Klremsssner PG, Wahlgre M, Carlson J: Blood group A antigen is a co-receptor in Plasmodium falciparum rosetting. Infection and Immunity 2000, 68:297I-5.

16. Pathirana SL, Alles HK, Bandara S, Phone-Kyaw M, Perera MK, Wickremasinghe AR, Mendis KN, Handunnetti SM: ABO-blood-group types and protection against severe, Plasmodium falciparum malaria. Ann Trop Med Parasitol 2005, 99(2): I 19-24.

17. Maubert B, Fievet N, Tami G, Boudin C, Deloron P: Plasmodium falciparum-isolates from Cameroonian pregnant women do not rosette. Parasite 1998, 5:28I-3.

18. Burrows TD, King A, Loke YW: Expression of adhesion molecules by endovascular trophoblast and decidual endothelial cells: implications for vascular invasion during implantation. Placenta 1994, I5(I):2 I-33.

19. Jones CJ, Santos TC, Abd-Elnaeim M, Dantzer V, Miglino MA: Placental glycosylation in peccary species and its relation to that of swine and dromedary. Placenta 2004, 25(7):649-57.

20. Skovlund VR: $\mathbf{A B H}$ and related histo-blood group antigens in normal \& malignant human endometrium in relation to genetic and hormonal factors. APMIS Suppl 1997, 69:1-33.

21. Ravn V, Dabelsteen E: Tissue distribution of histo-blood group antigens. APMIS 2000, 108:28.

22. Jones CJ, Dantzer V, Leiser R, Krebs C, Stoddart RW: Localisation of glycans in the placenta: a comparative study of epitheliochorial, endotheliochorial, and haemomonochorial placentation. Microsc Res Tech 1997, 38(I-2): 100-I4.

23. Thrower S, Bulmer JN, Griffin NR, Wells M: Further studies of lectin binding by villous and extravillous trophoblast in normal and pathological pregnancy. Int J Gynecol Pathol 199I, 10(3):238-5I.

24. Logie DE, McGregor IA, Rowe DS, Billewicz WZ: Plasma immunoglobulin concentrations in mothers and newborn children with special reference to placental malaria. Bull WId HIth Org 1973, 49:547-554.

25. von Seidlein L, Clarke S, Alexander N, Manneh F, Doherty T, Pinder $M$, Walraven G, Greenwood B: Treatment uptake by individuals infected with Plasmodium falciparum in rural Gambia, West Africa. Bull World Health Organ 2002, 80:790-796.

26. Bulmer JN, Rasheed FN, Francis N, Morrison L, Greenwood BM: Placental malaria. I. Pathological classification. Histopathology 1993, 22(3):2II-8.

27. Fried M, Duffy PE: Adherence of Plasmodium falciparum to chondroitin sulfate $\mathbf{A}$ in the human placenta. Science 1996, 272(5267): 1502-4.

28. Beeson JG, Rogerson SJ, Cooke BM, et al.: Adhesion of Plasmodium falciparum-infected erythrocytes to hyaluronic acid in placental malaria. Nat Med 2000, 6:86-90.

29. Rogerson SJ, Novakovic S, Cooke BM, Brown GV: Plasmodium falciparum-infected erythrocytes adhere to the proteoglycan thrombomodulin in static and flow-based systems. Exp Parasitol 1997, 86(I):8-18.

30. Blann AD, Daly RJ, Amiral J: The influence of age, gender and $A B O$ blood group on soluble endothelial cell markers and adhesion molecules. Br J Haematol 1996, 92(2):498-500.

31. Smith JD, Subramanian G, Gamain B, Baruch DI, Miller LH: Classification of adhesive domains in the Plasmodium falciparum erythrocyte membrane protein I family. Mol Biochem Parasitol 2000, I I 0(2):293-310.

32. Brustoski K, Kramer M, Moller U, Kremsner PG, Luty AJ: Neonatal and maternal immunological responses to conserved epitopes within the DBL-gamma3 chondroitin sulfate Abinding domain of Plasmodium falciparum erythrocyte membrane protein I. Infect Immun 2005, 73(I 2):7988-95.

33. Costa FT, Fusai T, Parzy D, Sterkers Y, Torrentino M, Douki JB, Traore B, Petres S, Scherf A, Gysin J: Immunization with recom- binant duffy binding-like-gamma3 induces pan-reactive and adhesion-blocking antibodies against placental chondroitin sulfate A-binding Plasmodium falciparum parasites. J Infect Dis 2003, I 88(I): I53-64.

34. Chen Q, Heddini A, Barragan A, Fernandez V, Pearce SF, Wahlgren $M$ : The semiconserved head structure of Plasmodium falciparum erythrocyte membrane protein I mediates binding to multiple independent host receptors. J Exp Med 2000, 192(I): I-10.

35. Wood CS: Preferential feeding of Anopheles gambiae mosquitoes on human subjects of blood group $O$ : A relationship between the $A B O$ polymorphism and malaria vectors. Hum Biol 1974, 46(3):385-404

36. Athreya $\mathrm{BH}$, Coriell LL: Relation of blood groups to infection. I. A survey and review of data suggesting possible relationship between malaria and blood groups. Am J Epidemiol 1967, 86(2):292-304.

37. Podbielska M, Fredriksson SA, Nilsson B, Lisowska E, Krotkiewski $\mathrm{H}$ ABH blood group antigens in O-glycans of human glycophorin A. Arch Biochem Biophys 2004, 429(2): 145-53.

38. Udoh AE: Distribution of sialic acid between sialoglycoproteins and other membrane components of different erythrocyte phenotypes. Acta Physiol Hung 1991, 78(3):265-73.

39. Kwiatkowski D: Genetic dissection of the molecular pathogenesis of severe infection. Intensive Care Med 2000, 26(Suppl I):S89-97.
Publish with Bio Med Central and every scientist can read your work free of charge

"BioMed Central will be the most significant development for disseminating the results of biomedical research in our lifetime. "

Sir Paul Nurse, Cancer Research UK

Your research papers will be:

- available free of charge to the entire biomedical community

- peer reviewed and published immediately upon acceptance

- cited in PubMed and archived on PubMed Central

- yours - you keep the copyright

Submit your manuscript here:

http://www.biomedcentral.com/info/publishing_adv.asp
BioMedcentral 